\title{
The decreasing radial wood stiffness pattern of some tropical trees growing in the primary forest is reversed and increases when they are grown in a plantation
}

\author{
J. Paul McLean • Tian Zhang • Sandrine Bardet • \\ Jacques Beauchêne - Anne Thibaut • Bruno Clair • \\ Bernard Thibaut
}

\begin{abstract}
- Background This study examines the radial trend in wood stiffness of tropical rainforest trees. The objective was to determine if the type of growing environment (exposed plantation or dense primary forest) would have an effect on this radial trend.

- Methods The axial elastic modulus of wood samples, representing a pith to bark cross-section, of six trees from several French Guianese species (two of Eperua falcata, one of Eperua grandiflora, two of Carapa procera and one of Symphonia gloubulifera) was measured using a dynamic "forced vibration" method.

- Results Primary forest trees were observed to have a decrease in wood stiffness from pith to bark, whereas plantation trees, from the same genus or species, displayed a corresponding increase in wood stiffness. Juvenile wood stiffness appears to vary depending on the environment in which the tree had grown.

- Conclusion We suggest that the growth strategy of primary forest trees is to produce wood resistant to selfbuckling so that the height of the canopy may be obtained
\end{abstract}

with the maximum of efficiency. In contrast, the growth strategy of the trees growing in an exposed plantation is to produce low-stiffness wood, important to provide flexibility in wind. Further experiments to study the behaviour of more species, with more individuals per species, growing across a range of physical environments, are required.

Keywords Tropical trees · Growth strategy - Wood stiffness · Juvenile wood

\section{Introduction}

In addition to the transport of water and nutrients, wood plays a structural role of providing support for a living tree. As the tree grows, its structural requirements change, and therefore the mechanical properties of the wood it produces alter as a function of age (cambial age). Physical differences in the wood structure between juvenile and mature wood usually result in a difference in: i) density, ii) stiffness (measured as longitudinal modulus of elasticity or MOE), and therefore iii) specific MOE (MOE divided by density). MOE of wood is inversely related to the cellulose microfibril angle (MFA) in the S2 layer (Cowdrey and Preston 1966; Cave 1968) and positively related to density (Kollman and Côté 1984; Zobel and van Buijeten 1989). The specific MOE is therefore inversely related to MFA (Evans and Ilic 2001).

Studies on wood stiffness in relation to cambial age carried out on mature gymnosperm trees (e.g., Leban and Haines 1999; Koponen et al. 2005; McLean 2008) show an increase in MOE from the pith to the bark. Additionally, MFA typically decreases from pith to bark (Barnett and Bonham, 2004). Therefore, wood produced early in the life 
of a tree is more flexible than that produced in the later years. This means that stem flexibility of the juvenile tree is high when compared to the mature tree. Given the increase in specific MOE, or decrease in MFA with age, authors often surmise that flexible wood in the young tree is desirable to prevent wind damage (e.g., Telewski 1989, Barnett and Bonham 2004,).

Studies on angiosperms likewise show that MOE usually increases from pith to bark (Bendsten and Senft 1986; Adamopoulos et al. 2007). However, the difference between juvenile and mature wood is less marked in hardwoods than in softwoods (Bao et al. 2001) and in some species, such as Oregon white oak (Quercus garryana Dougl.) (Gartner et al. 1995) or slowly grown plantation teak (Tectona grandis L. F.) (Bhat et al, 2001), no difference in MOE is observed between juvenile and mature wood. Niklas (1997) presented a study on black locust (Robina pseudoacacia L.) in which wood MOE declined from pith to bark, in contrast to the typical pattern described above, though a later study on the same species reported the typical increasing pattern (Adamopoulos et al. 2007). Niklas (1997) described two categories of tree architecture: the "rigid rind" construction in which the exterior tissues are more rigid than the interior, and a "rigid core" construction in which the exterior tissues are less rigid than those in the centre. However, Niklas (1997) did not put forward any reason why some trees produce the rigid core structure. Woodcock and Shier (2002), using wood specific gravity of temperate hardwood species as a proxy for wood stiffness, found that within one species there could be radial specific gravity increases in some individuals and radial decreases in others. Woodcock and Shier (2002) found this opposing trend in the same species "difficult to understand". Looking at data from tropical woods, it was found that MOE and specific MOE of Eperua falcata grown in primary forest in French Guiana decreased from pith to bark (Thibaut et al 2006), the opposite to the typical juvenile wood pattern.

Christensen-Dalsgaard et al (2008) concluded that: "radial anatomical patterns are not a passive function of cambial ageing but may be modified in response to local mechanical loading." We therefore postulated that the radial changes in wood mechanical properties can be related to the environment during the early life of the tree, where juvenile wood stiffness can be altered in function depending on the localised environment. Further, we expected that trees growing in an open environment and subject to wind loading would produce flexible wood, whereas trees in competition for light would produce stiffer wood. To test this hypothesis, we collected data on radial trends in wood properties from species growing in the primary forest of French Guiana and in a nearby plantation.

\section{Materials and methods}

\subsection{Sample material}

Wood was studied from six individual trees: three from the genus Eperua (two E. falcata and one E. grandiflora, the common name for both is wapa), two Carapa procera (common name carapa), and one Symphonia globulifera (common name symphonia); all growing within a $70-\mathrm{km}$ radius of Kourou, French Guiana. Of these trees, two $E$. falcata $\left(\mathrm{DBH}=42 \mathrm{~cm}\right.$ approx., N 05 $1051.283^{\prime} \mathrm{W} 52^{\circ}$ $\left.43.134^{\prime}\right)$, one Symponia globulifera $\left(\mathrm{DBH}=57 \mathrm{~cm}, \mathrm{~N} 05^{\circ}\right.$ $\left.17.088^{\prime} \mathrm{W} 52^{\circ} 54.811^{\prime}\right)$ and one $C$. procera $(\mathrm{DBH}=49 \mathrm{~cm}$, $\mathrm{N} 05^{\circ} 17.101^{\prime} \mathrm{W} 52^{\circ} 54.764^{\prime}$ ) came from primary forest. One E. grandiflora $(\mathrm{DBH}=22 \mathrm{~cm}$ approx.) and one $C$. procera $(\mathrm{DBH}=34 \mathrm{~cm})$ came from a 26 -year-old plantation ( $\mathrm{N} 04^{\circ} 48.123$ ' W 52 20.742 '). Information on sample material is given in Table 1 .

The sampled trees were felled, and a disc of $\sim 400 \mathrm{~mm}$ long was processed into small boards $\left(600 \times 200 \times 20 \mathrm{~mm}^{3}\right.$, $\mathrm{L} \times \mathrm{R} \times \mathrm{T})$ that were first air-dried. At this point, due to independent experimenters, sample preparation sometimes differed among trees (Fig. 1). For the three Eperua trees small samples, of dimensions $150 \times 2 \times 12 \mathrm{~mm}^{3}(\mathrm{~L} \times \mathrm{R} \times \mathrm{T})$, were cut from the air dried boards from the pith to the bark (Fig. 1i). For the primary forest C. procera and S. globulifera trees, samples were $200 \times 8 \times 2 \mathrm{~mm}^{3}(\mathrm{~L} \times \mathrm{R} \times \mathrm{T})$, and came from three (S. globulifera ) or five radial (C. procera) groups (Fig. 1ii) that corresponded to increasing distances from the pith. Each group contained 15-21 samples. For the plantation C. procera tree, samples $\left(200 \times 2.5 \times 8 \mathrm{~mm}^{3}\right.$, $\mathrm{L} \times \mathrm{R} \times \mathrm{T}$ ) were cut in a fashion that radiated outwards from the pith across the diameter of the disc (Fig. 1i); however, in order to standardise data presentation within this species, these samples were split into five radial groups (similar to Fig. 1ii, but with $\mathrm{T}>\mathrm{R}$ ) according to distance from the pith (i.e., group 1 was those samples 0 $30 \mathrm{~mm}$ from the pith, group 2 was those samples 30$60 \mathrm{~mm}$ from the pith, and so on), each of which contained between eight and 11 samples. Crucially, regardless of the preparation, sample dimensions were always the same for each tree, and had a high length to depth ratio to allow measurement of MOE from vibratory tests. The long, thin samples from each tree were collectively conditioned to the same moisture content $(10.2,11.0$ or $13.2 \%$ depending on season) in the laboratory for at least 1 week prior to measurement of mechanical properties.

\subsection{Dynamic modulus measurements}

The dynamic MOE of each sample was estimated by the forced vibration test (Obataya et al. 2000), using the 
Table 1 Sample material used in the study

\begin{tabular}{|c|c|c|c|c|c|c|c|c|}
\hline Location & Type & Species & Quantity & Age (years) & Height (m) & Dominance class & $\begin{array}{l}\text { Stand average } \\
\text { height }(\mathrm{m})\end{array}$ & Trees/ha \\
\hline L'Egypienne & Plantation & Eperua grandiflora & 1 & 26 & 22 & $\mathrm{n} / \mathrm{a} \geq 5 \mathrm{~m}$ spacing & 25 & $\sim 400^{\mathrm{a}}$ \\
\hline Kourou & Natural forest & Eperua falcata & 2 & Unknown & 30 & Dominant & 38 & Unknown $^{\mathrm{b}}$ \\
\hline Paracou & Plantation & Carapa procera & 1 & 26 & 25 & $\mathrm{n} / \mathrm{a} \geq 5 \mathrm{~m}$ spacing & 25 & $\sim 400^{\mathrm{a}}$ \\
\hline Paracou & Natural forest & Symphonia globulifera & 1 & Unknown & 33 & Dominant & 38 & Unknown $^{\mathrm{b}}$ \\
\hline
\end{tabular}

a. The exact figure is unknown but stocking density was sparse; this figure is deemed representational by the French forest service (Office National de Forêts)

b. The quantity of trees in one hectare of primary Amazon forest in this region is normally in excess of 3,000, with some 600 of those having a diameter of $>10 \mathrm{~cm}$

apparatus developed by Brémaud (2006). Before testing, the mass (Sartorius balance $\pm 0.1 \mathrm{mg}$ ) and dimensions (Mitutoyo comparator $\pm 5 \mu \mathrm{m}$ for $\mathrm{R}$ and $\mathrm{T}$, Mitutoyo calliper $\pm 20 \mu \mathrm{m}$ for L) of each air-dried sample were measured, and volumetric density was calculated from these values. For the forced vibration test, samples were balanced on fine threads positioned at the vibration nodes of the first resonance mode to allow freedom of movement. A very small metal piece was glued to the end of the specimen, which was then forced to vibrate using an electromagnet connected to a periodic electrical current of increasing frequency $(150-1000 \mathrm{~Hz})$. A laser measured deflection at the mid-point of the sample beam, and the signals were analysed by a dedicated computer running Labview ${ }^{\circledR}$ software to determine the first resonance frequency. Specific MOE was then calculated using the Euler-Bernouilli equation. Each sample was measured three times to ensure the measurements were consistent; the final specific MOE obtained for each sample was the mean of the three measurements. Sample MOE was further calculated as the product of specific MOE and sample density. After testing, the samples were oven-dried to ensure that all samples originating from the same tree were tested at the same moisture content.

\subsection{Statistical methods}

To determine the significance of group (therefore radial position) on density, MOE and specific MOE of the $C$. procera and $S$. globulifera samples, a generalised linear model (GLM) was constructed:

$Y=R+\varepsilon$

where $\mathrm{Y}$ is the MOE, density or specific MOE, $R$ is the group denoting radial position and $\varepsilon$ the residuals. This model was fitted individually to each tree, and an F test in ANOVA was used to assess the significance at $\alpha=0.05$. Where a significant difference was found in ANOVA, a post-hoc Tukey HSD was used to determine which groups were significantly different from each other. Model residuals were always tested for normality. All statistical analysis and graphics were performed and produced using the $\mathrm{R}$ open source software (R Development Core Team 2008).

\section{Results}

For the E. falcata samples, there was no obvious radial trend observed in wood density (Fig. 2i) with increasing
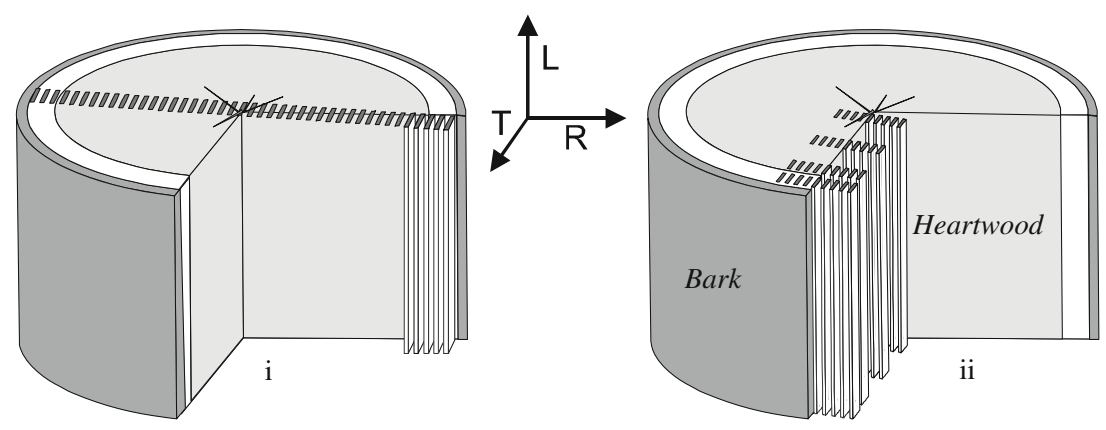

Fig. 1 Preparation of thin tropical wood samples for dynamical measurements of modulus of elasticity (MOE). Samples from two Eperua falcata growing in the primary forest and one Eperua grandiflora were prepared according to (i). Samples from one Carapa procera and one Symphonia globulifera growing in the primary forest were prepared according to $(\mathrm{ii})$ 
Fig. 2 The radial pith to bark trend in wood density $(i \& i i)$, modulus of elasticity or MOE (iii \& iv) and specific MOE $(v \& v i)$ in two primary forest Eperua falcata trees $(+$ and $\bullet)$ and one plantation-grown Eperua grandiflora (O) growing in French Guiana
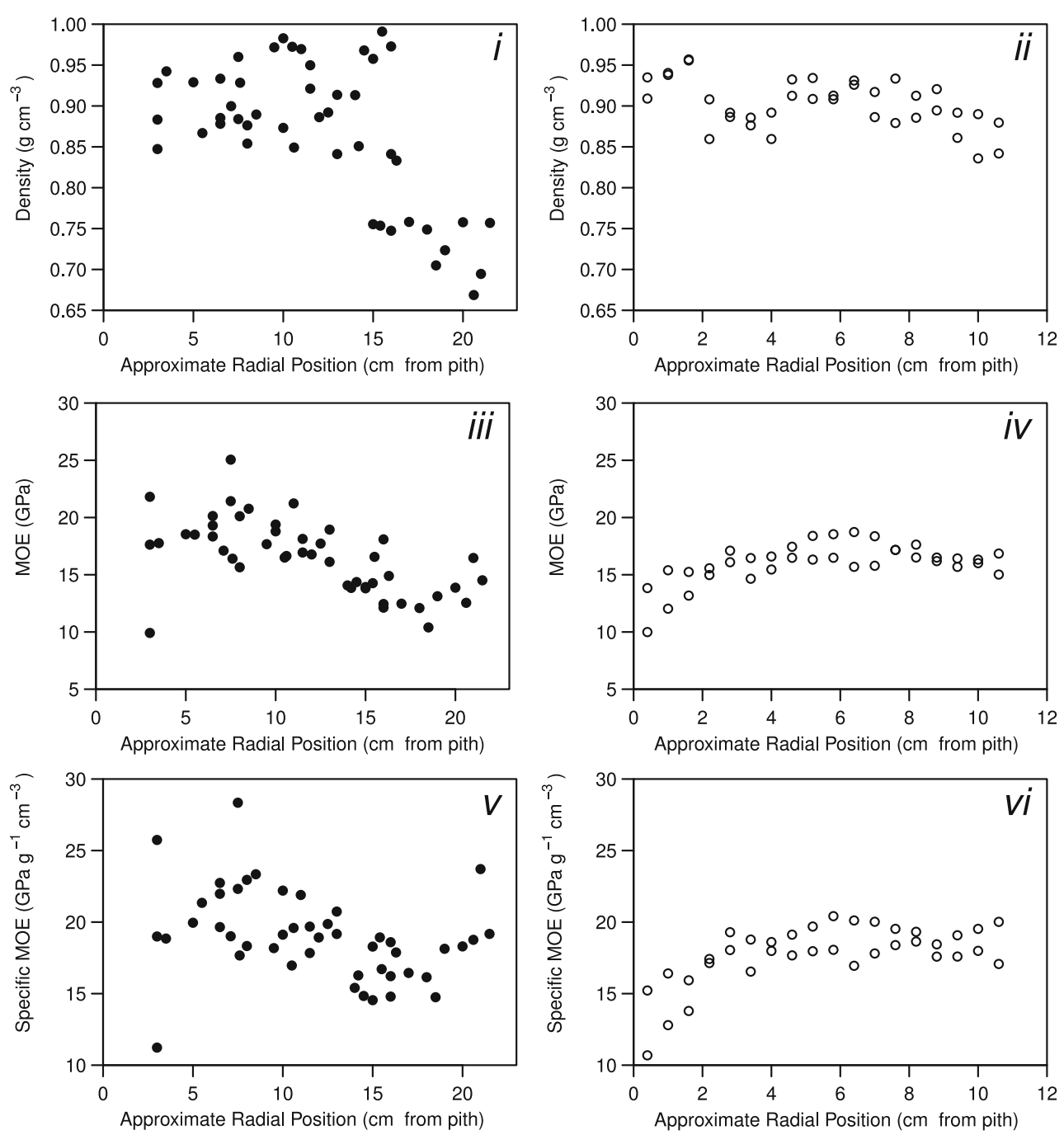

distance from the pith, except for a drop in wood density by approximately $0.2 \mathrm{~g} \mathrm{~cm}^{-3}$, or $\sim 18 \%$, at $\sim 17 \mathrm{~cm}$ from the pith, and corresponding to the heartwood/sapwood boundary. The wood density of the E. grandiflora samples (Fig. 2ii) also displayed no obvious radial trend. For the primary forest E. falcata samples, a pith to bark increase in MOE and specific MOE (Fig. 2iii \& v) was observed, whereas the plantation E. grandiflora samples showed a pith to bark increase for these two variables (Fig. 2 iv \& vi).

The $C$. procera primary forest tree had an irregular trend in wood density (Fig. 3i). There was a significant effect of radial position in ANOVA $\left(\mathrm{F}_{4,75}=24.8, p<0.001\right)$ and a post hoc Tukey HSD $(p<0.05)$ showed that there was a drop, then rise, then drop in wood density without the mean difference ever exceeding $0.05 \mathrm{~g} \mathrm{~cm}^{-3}$. For the plantation $C$. procera (Fig. 3ii) radial position had a significant effect on wood density in ANOVA $\left(\mathrm{F}_{4,46}=15.6, p<0.001\right)$; further examination of the GLM showed an general significant increase in wood density, with the greatest mean difference of $0.12 \mathrm{~g} \mathrm{~cm}^{-3}$ between the innermost and outermost samples. MOE and specific MOE (Fig. 3iii \& iv) decreased from pith to bark $\left(\mathrm{F}_{4,75}=89.8, p<0.001\right.$ and $\mathrm{F}_{4,75}=165.5$, $p<0.001$ respectively in ANOVA) for the primary forest $C$. procera, with an overall mean decrease of $8.2 \mathrm{GPa}$ in MOE and $19.2 \times 10^{6} \mathrm{~m}^{2} \mathrm{~s}^{-2}$ in specific MOE between the innermost and outermost samples. The plantation $C$. procera samples showed an increase in MOE and specific $\operatorname{MOE}\left(\mathrm{F}_{4,42}=14.9\right.$, $p<0.001$ and $\mathrm{F}_{4,42}=5.6, p<0.001$ respectively in ANOVA), with an overall mean increase of 4.6 GPa in MOE and $3.3 \times$ $10^{6} \mathrm{~m}^{2} \mathrm{~s}^{-2}$ in specific MOE between the innermost and outermost samples. The difference between the mean specific MOE of the primary forest and plantation innermost samples was $13.5 \times 10^{6} \mathrm{~m}^{2} \mathrm{~s}^{-2}$, and the difference between the outermost samples was $2.2 \times 10^{6} \mathrm{~m}^{2} \mathrm{~s}^{-2}$.

The $S$. globulifera primary forest tree had an irregular trend in wood density (Fig. 4i). There was a significant effect of radial position in ANOVA $\left(\mathrm{F}_{2,42}=24.8, p<0.001\right)$ and a post hoc Tukey HSD $(p<0.05)$ showed that there was a drop, then rise, then drop in wood density without the mean difference ever exceeding $0.05 \mathrm{~g} \mathrm{~cm}^{-3}$. MOE and specific 
Fig. 3 The radial pith to bark trend in wood density $(i \& i i)$, modulus of elasticity or MOE (iii \& iv) and specific $\operatorname{MOE}(v \& v i)$ in one primary forest Carapa procera tree ( $i$, iii \& $v$ or left hand side) and one plantation grown Carapa procera tree (ii, iv \& $v i$ or right hand side) growing in French Guiana
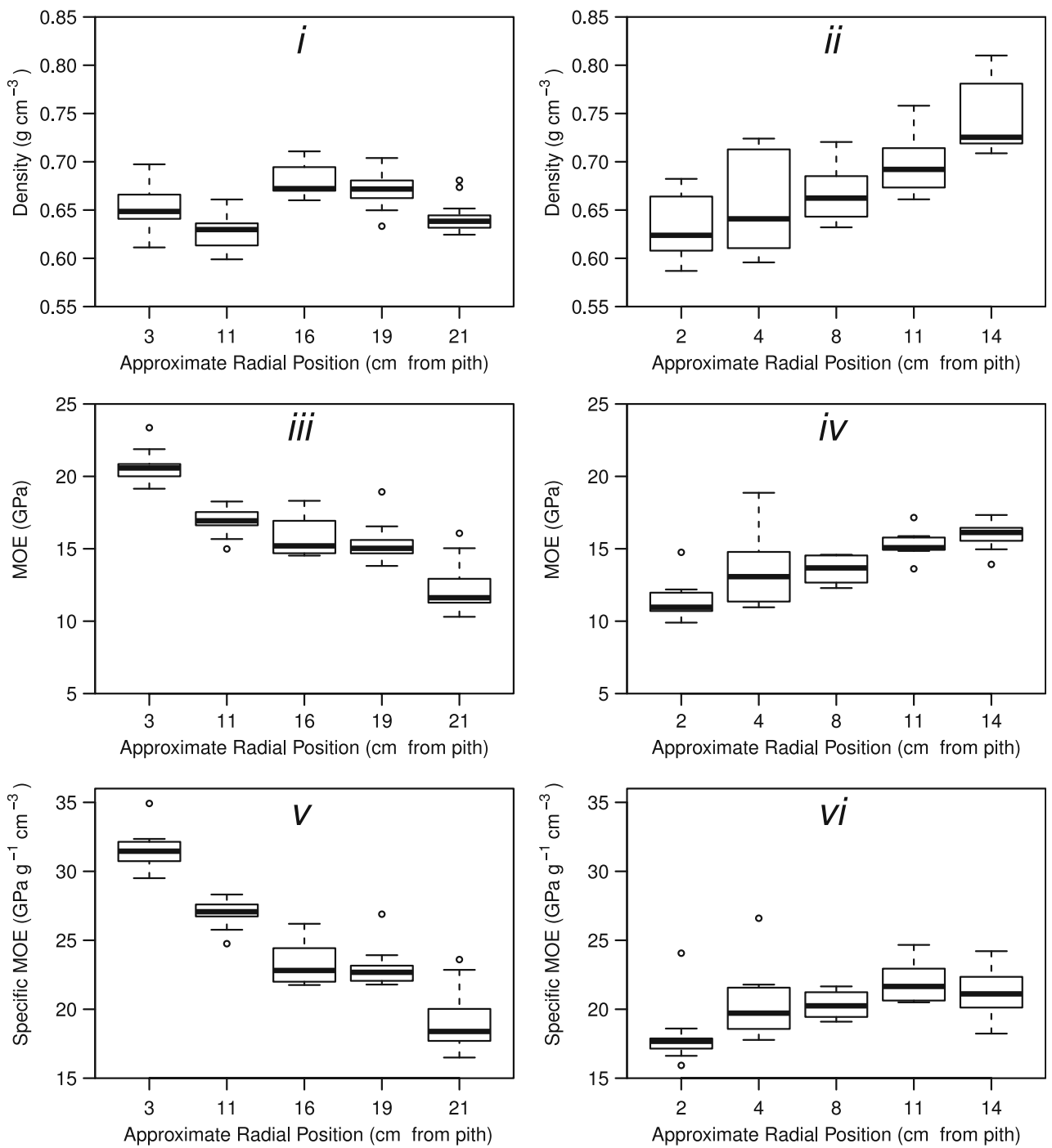

MOE of the primary forest $S$. globulifera tree (Fig. 4ii \& iii) decreased from pith to bark $\left(\mathrm{F}_{2,42}=78.1, p<0.001 \& \mathrm{~F}_{2,42}=\right.$ 203.0, $p<0.001$ respectively in ANOVA), with an overall mean decrease of $3.52 \mathrm{GPa}$ in $\mathrm{MOE}$ and $5.80 \times 10^{6} \mathrm{~m}^{2} \mathrm{~s}^{-2}$ in specific MOE between the innermost and outermost samples

\section{Discussion}

The sudden drop in wood density of the primary forest $E$. falcata trees is linked to heartwood formation. Extractives formed during heartwood formation increase wood density, but are not known to contribute to wood stiffness. The difference between heartwood and sapwood in the primary forest $E$. falcata samples corresponds to the $\sim 20 \%$ (mass of extractives as percentage of dry mass) extractive content for this species (CIRAD database, Royer et al. 2010). Therefore, in the case of E. falcata, if the density of the heartwood samples in Fig. $2 \mathrm{i}$ is reduced by $20 \%$ we would observe no radial trend. According to a database held by
CIRAD, C. procera \& S. globulifera are species with a low extractive content $(\sim 7 \%)$, and thus there is no obvious heartwood to sapwood transition, in terms of wood density, for these species. Our density measurements would have been more valid had extraction been systematically performed. Nevertheless, other than the density increase observed for the plantation $C$. procera, density of these trees did not change by a great extent between the pith and the bark, and the radial trends in wood stiffness discussed below are most probably due to the radial trend in MFA.

There is a clear difference in the radial trend in wood mechanical properties between trees that had grown in primary forest and those that had grown in the plantation. MOE and specific MOE decreased (denoting an increase in MFA) from pith to bark for the trees from the primary forest (E. falcata, C. procera \& S. globulifera), and increased (denoting a decrease in MFA) from pith to bark for the trees from the plantation (E. grandiflora and C. procera; unfortunately, $S$. globulifera growing in a plantation was not available). 

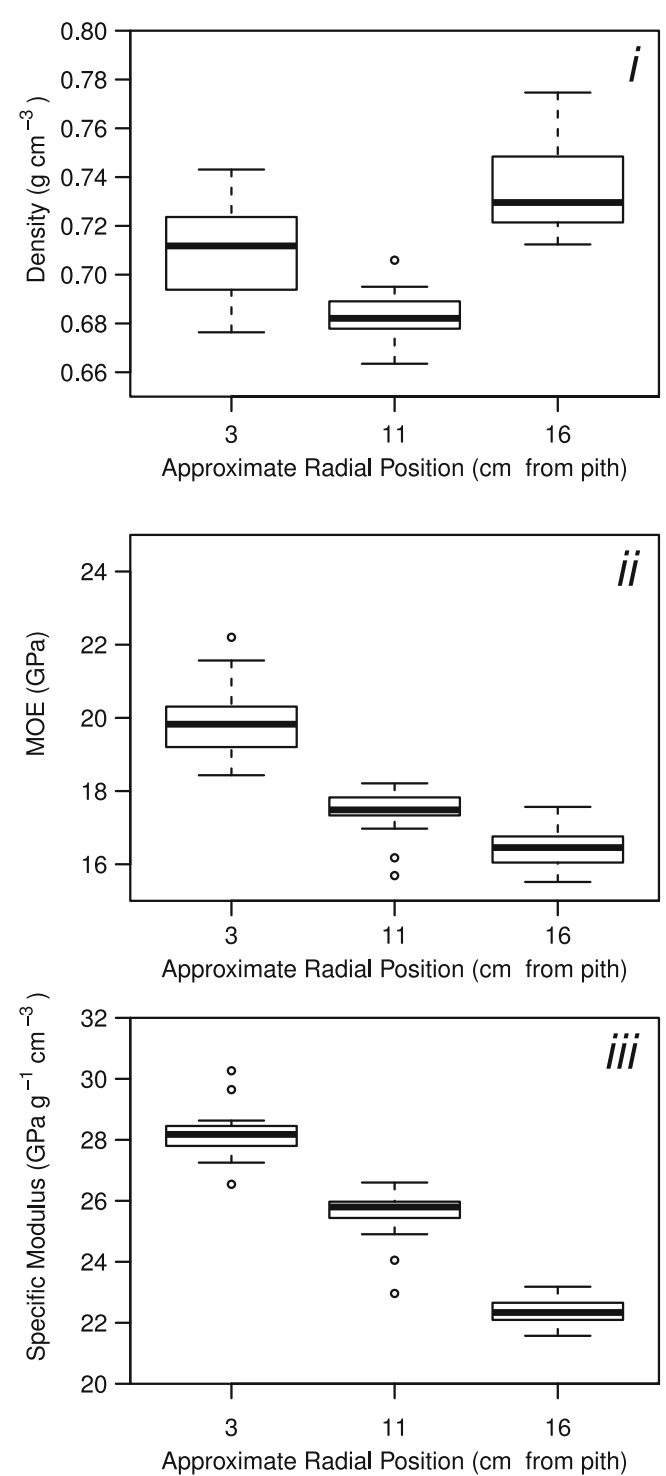

Fig. 4 The radial pith to bark trend in wood density $(i)$, modulus of elasticity or MOE (ii) and specific MOE (iii) in one primary forest Symphonia globulifera tree growing in French Guiana

The specific MOE for trees from primary forest and plantation, within each genus, was of approximately the same value for samples from the outer part of the tree. Therefore we believe, as did Woodcock and Shier (2002), that the mature wood possesses stiffness of an optimal value for a fully grown canopy tree. In fact, it is not so important for a living tree whether there is an increase or decrease in wood stiffness from pith to bark, and it is difficult to imagine what mechanical advantage a 'RigidCore' or 'Rigid-Rind' (terms Niklas 1997 used to describe a decrease or increase, respectively, from pith to bark in MOE) gives to a large canopy tree, as the stem flexibility is dictated by the MOE of the wood at the outer part of the tree. In reality, the radial pith to bark trend in wood stiffness simply tells the mechanical life history of the tree's growth, as wood toward the interior has already performed its primary structural duty; the remaining requirement is only that it support the compressive self-loading of the tree. What is really important in our results is the fact that the juvenile wood, for the trees growing in primary forest, was not more flexible than the mature wood. Therefore, juvenile wood in trees is not by default more flexible than mature wood, and increasing wood stiffness in trees is not a function of passive cambial aging. Instead, wood is produced as a function of the imposed environmental constraints (Christensen-Dalsgaard et al. 2008).

Tropical woody climbers, which occur sympatrically with the species studied, alter the stiffness of wood produced in function of the imposed mechanical environment. Climbers, like the primary forest trees in this study, produce very stiff juvenile wood, as they grow in search of light and host support, at which point their structure becomes supple to adapt to growth of the host (Rowe et al, 2006, Menard et al. 2009). We must pose the question: if woody climbers can do it, why can't trees?

Consider the environment of the young tree growing in a plantation; it is exposed, and wind-loading is always present. The young plantation tree produces wood that has a low MOE and specific MOE. This means that this young tree is more flexible, the whole trunk being able to assume a higher curvature without damage. This is a good option for reducing wind loads. Further, Cordero (1999) found that the pioneering Cecrophia schreberiana changed flexural stiffness based on wind regimes, whereby wind-exposed stems were much more flexible than those that were sheltered, providing evidence of the active cambial response to wind loading. In fact, most of the studies on juvenile wood properties (e.g., those made on MFA and listed by Barnett and Bonham 2004) were made on trees that grew first in open environment, where wind action is always present. Now consider the environment of the young tree in growing in dense primary forest. The young tree is sheltered from wind from the very beginning but light is scarce, limiting photosynthesis and potential biomass production. Therefore, the young tree tries to grow in height as efficiently (i.e., lowest biomass input) as possible in obtain more light. The result is that when growing in primary forest, the opposite trend in juvenile wood stiffness appears: high MOE and specific MOE. This means that the young tree in primary forest is less adapted to wind-loading, but in the sheltered environment of the primary forest the danger arises more from self-buckling than flexure under wind action. Examination of Greenhill's formula in Jaouen et al. (2007) shows that, for a tree stem, specific MOE is the governing mechanical parameter in the maximum height it can achieve before self-buckling. Increased specific MOE allows the tree a greater height to diameter ratio, i.e., slenderness. 
Recent silvicultural studies (Watt et al. 2006; Waghorn et al. 2007), where Greenhill's equation was also considered, showed that young Pinus radiata growing in New Zealand increased wood stiffness as a means to increase slenderness in response to increased competition (decreased spacing) from neighbouring trees, proof of the cambial response to reduced light availability. Supporting evidence may also be drawn from studies which examine wood stiffness as a function of succession. Here, late successors, or shade-tolerant, species are found to produce stiffer (Alvarez-Clare 2005, van Gelder et al. 2006) wood than primary successors, or shade-intolerant species. The same species are not compared in both exposed and sheltered environments, but the evolutionary benefits of stiffer wood for life in the tropical understory or flexible wood in exposed clearings are discussed by van Gelder et al. (2006), who concur with our suggestions.

Due to the few trees and species used in our experiment, it is impossible to conclude whether this biomechanical adaptation is common to all species. Specific experiments comparing growth of trees from the same species in primary forest, plantation and intermediate environments (when available) are needed.

\section{Conclusion}

From our experiments, it seems that during the juvenile phase of tree growth, the choice in peculiar mechanical wood properties in the trunk seemingly results from a biomechanical adaptation much more than from a passive function of cambial ageing. This could be regulated through the MFA during fibre differentiation in the cambial zone. Species normally found growing in primary forest seem to be able to adapt wood produced during the early stages of growth to life in an open environment.

Acknowledgements This research has been performed in the framework of the project "Woodiversity" supported by the French National Research Agency (ANR-05-BDIV-012-04). The authors would like to thank the associate editor Barry Gardiner and the two anonymous reviewers for their extremely helpful comments to improve this manuscript. Also thanks to Professor Philip J. Harris, University of Auckland, for reviewing the language of the final version.

\section{References}

Adamopoulos S, Passialis C, Voulgardis E (2007) Strength properties of juvenile and mature wood in black locust (Robinia pseudoacacia L.). Wood Fiber Sci 39(2):241-249

Alvarez-Clare S (2005) 'Biomechanical properties of tropical tree seedlings as a functional correlate of shade tolerance', Master's Thesis, University of Florida
Bao FC, Jiang ZH, Jiang XM, Lu XX, Luo XQ, Zhang SY (2001) Differences in wood properties of 10 species grown in China. Wood Sci Technol 35:363-375

Barnett JR, Bonham VA (2004) Cellulose microfibril angle in the cell wall of wood fibres. Biol Rev 79:461-472

Bendsten BA, Senft J (1986) Mechanical and anatomical properties in individual growth rings of plantation-grown eastern cotton wood and loblolly pine. Wood Fiber Sci 18:23-38

Bhat KM, Priya PB, Rugmini P (2001) Characterisation of juvenile wood in teak. Wood Sci Technol 34:517-532

Brémaud I (2006) 'Diversité des bois utilisés ou utilisables en facture d'instruments de musique. », PhD thesis, Université de Montpellier 2, $294 \mathrm{p}$

Cave ID (1968) Anisotropic elasticity of plant cell wall. Wood Sci Technol 2:268-278

Christensen-Dalsgaard KK, Ennos AR, Fournier M (2008) Are radial changes in vascular anatomy mechanically induced or an ageing process? Evidence from observations on buttressed tree root systems. Trees 22:543-550

Cordero RA (1999) Ecophsiology of Cecropia schreberiana saplings in two wind regimes in an elfin cloud forest: growth, gas exchange, architecture and stem biomechanics. Tree Physiol 19:153-163

Cowdrey DR, Preston RD (1966) Elasticity and microfibrillar angle in wood of Sitka spruce. Proc Roy Soc B 166:245-272

Evans R, Ilic J (2001) Rapid prediction of wood stiffness from microfibril, angle and density. For Prod J 51:53-57

Gartner BL, Lei H, Milota MR, Evans JW, Senft JF, Green DW (1995) 'Juvenile/mature wood effects in two western hardwoods: anatomy and mechanical properties' In: Green D et al. (eds) Western Hardwoods: Value-Added Research and Demonstration Program USDA Forest Service, General Tech. Report FPL-GTR-85

Jaouen G, Alméras T, Coutand C, Fournier M (2007) How to determine sampling buckling risks with only a few measurements. Am J Bot 94(10):1583-1593

Kollman F, Côté W (1984) "Principles of wood science and technology. Vol. 1: Solid wood". Springer, Berlin, pp 1-592

Koponen T, Karppinen T, Heeggstrom E, Saranpaa P, Serimaa R (2005) The stiffness modulus in Norway spruce as a function of year ring. Holzforschung 59:451-455

Leban JM, Haines DW (1999) The modulus of elasticity of hybrid larch predicted by density, rings per centimeter, and age. Wood Fiber Sci 31:394-402

McLean JP (2008) 'Wood properties of four genotypes of Sitka spruce', $\mathrm{PhD}$ thesis, The University of Glasgow

Menard L, McKey D, Rowe N (2009) Developmental plasticity and biomechanics of treelets and lianas in Manihot aff. quinquepartita (Euphorbiaceae): a branch-angle climber of French Guiana. Ann Bot 103(8): 1249-1259

Niklas KJ (1997) Mechanical properties of black locust (Robinia pseudoacacia) wood: Correlations among elastic and rupture moduli, proportional limit, and tissue density and specific gravity. Ann Bot 79(5):479-485

Obataya E, Ono T, Norimoto M (2000) Vibrational properties of wood along the grain. J Mater Sci 35:2993-3001

R Development Core Team (2008) R: A language and environment for statistical computing. R Foundation for Statistical Computing, Vienna, Austria. ISBN 3-900051-07-0, URL http://www.Rproject.org

Rowe NP, Isnard S, Gallenmüller F, Speck T (2006) Diversity of mechanical architectures in climbing plants: an ecological perspective. In: Herrel A, Speck T, Rowe NP (eds) Ecology and biomechanics: a mechanical approach to the ecology of animals and plants. Taylor \& Francis, Boca Raton, pp 35-59

Royer M, Stein D, Beauchêne J, Herbette G, McLean JP, Thibaut A, Thibaut B (2010) Extractives of the tropical wood wallaba (Eperua 
falcata Aubl.) as natural anti-swelling agents. Holzforschung 64(2):211-215

Telewski FW (1989) Structure and function of flexure wood in Abies fraseri. Tree Physiol 5:113-121

Thibaut B, Thibaut A, Beauchêne J, Ruelle J (2006) Unusual juvenile wood features in Eperua falcata (Aubl.): an adaptive choice to cope with mechanical instabilities during early growth in tropical rain forest. In: L. Salmén (ed), Proceedings of the fifth plant biomechanics conference, 1:99-102, Stockholm (Sweden) August 28-September 1, 2006, STFI-Packforsk AB

Van Gelder HA, Poorter L, Sterck FJ (2006) Wood mechanics, allometry, and lifehistory variation in a tropical rain forest tree community. New Phytologist 171(2):367-378
Waghorn MJ, Mason EG, Watt MS (2007) Influence of initial stand density and genotype on longitudinal variation in modulus of elasticity for 17-year-old Pinus radiata. For Ecol Manag 252:6792

Watt MS, Moore JR, Facon JP et al (2006) Modelling environmental variation in Young's modulus for Pinus radiata and implications for determination of critical buckling height. Ann Bot 98:765775

Woodcock DW, Shier AD (2002) Wood specific gravity and its radial variations: the many ways to make a tree. Trees Struct Funct $16: 437-443$

Zobel BJ, van Buijeten JP (1989) Wood variation: its causes and control. Springer, Berlin 